\title{
Investigation of the antioxidant effects of pheniramine maleate and nebivolol on testicular damage in rats with experimentally induced testis torsion ${ }^{1}$
}

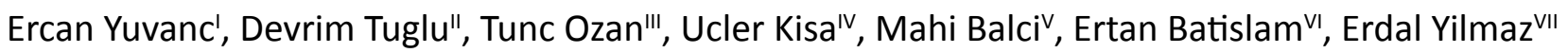

'Assistant Professor, Department of Urology, Medical Faculty, University of Kirikkale, Turkey. Design of the study, analysis of data, technical procedures, manuscript writing.

"Assistant Professor, Department of Urology, Medical Faculty, University of Kirikkale, Turkey. Technical procedures, acquisition of data, manuscript writing.

"'Assistant Professor, Department of Urology, Medical Faculty, University of Firat, Elazıg, Turkey. Intellectual and scientific content of the study, statistical analysis, critical revision, final approval.

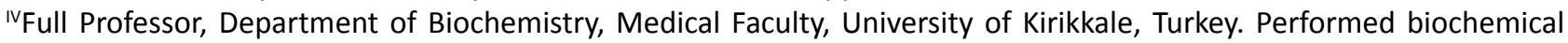
results.

${ }^{v}$ Assistant Professor, Department of Pathology, Medical Faculty, University of Kirikkale, Turkey. Macroscopic and histopathological examinations.

VIFull Professor, Department of Urology, Medical Faculty, University of Kirikkale, Turkey. Conception and design of the study, interpretation of data.

VIIFull Professor, Department of Urology, Medical Faculty, University of Kirikkale, Turkey. Critical revision, final approval.

\begin{abstract}
Purpose: To investigate the biochemical, histopathologic, and spermatogenetic changes in the detorsionated testicle after experimental torsion and to study the antioxidant effects of pheniramine maleate and nebivolol.

Methods: Twenty-four Sprague-Dawley male rats were divided into 4 groups: Group 1: Sham; Group 2: Torsion/Detorsion (T/D); Group 3: T/D + Pheniramine maleate (PM); Group 4: T/D + Nebivolol (NB) group. Paroxanase (PON), total antioxidant status (TAS), total oxidant status (TOS), and oxidative stres index (OSI) were measured, and spermatogenetic and histopathologic evaluation was performed in tissue and blood samples.

Results: The evaluation of tissue TAS indicated no statistically significant difference in Group 3 compared to Group 2. A statistically significant increase was detected in Group 4 compared to Group 2. Serum PON levels revealed a statistically significant increase in Groups 3 and 4 compared to Groups 1 and 2. The Johnsen testicular biopsy score decreased in Groups 3 and 4 , but the decrease was not statistically significant.

Conclusions: Pheniramine maleate and nebivolol have antioxidant effects against ischemiareperfusion damage. They also support tissue recovery, which is more significantly observed by nebivolol.
\end{abstract}

Key words: Testis. Spermatic Cord Torsion. Pheniramine. Nebivolol. Oxidative Stress. Rats. 


\section{- Introduction}

An acute scrotum is a pediatric urologic emergency and commonly presentesas the torsion of the testis or appendix testis. Testicular torsion occurs due to rotation of the spermatic cord and its accessories because of the anastomosis free terminal testicle artery and the nonelastic structure of the tunica albuginea, leading to the blockage of the arterial and venous blood flow.

Besides the blockage of testicular blood flow, ischemia reperfusion (I/R) damage developing due to the defense system of the testicle plays an important role in the formation of atrophy and loss of testicular functions. It is believed that detorsion of the testis and the resulting reperfusion alone may not be sufficient for preventing testicular damage, and the antioxidant factors have attracted interest in recent years due to their damage-prevention and recovery effect.

Pheniramine maleate (PM) is an alcylamine-derived $\mathrm{H} 1$ antihistaminic, mostly used for the symptomatic treatment of allergies and the flu due to its high agregation capacity to cell membranes because of its lipophilic features and resulting prevention of the formation and/or secretion of free radicals and its anti-inflammatory effect ${ }^{1}$.

Nebivolol (NB) is a third -highly selective beta-1 receptor antagonist used orally to treat arterial hypertension. Its long-term use has been shown to support endothel function, to prevent the formation of vascular super oxide by producing NADPH oxidase, and to supress vascular oxidative stress in antihypertensive treatment doses ${ }^{2,3}$.

There are studies on the antioxidant function of PM and NB on several tissues, but to our knowledge, this is the first study on their effect in testis tissue and I/R damage. The study has three aims: to evaluate the histopathologic, biochemical, and spermatogenetic changes in the ipsilateral testis tissue after torsion and to investigate the effects of PM and NB on detorsionated testis tissue.

\section{Methods}

This experimental study was approved by the local animal experiments ethic commitee (06.03.14/275) according to the Declaration of Helsinki and performed in the Experimental Animal Laboratory of Ankara Training and Research Hospital. The animals were maintained and used in accordance with the Animal Welfare Act and the Guide for the Care and Use of Laboratory Animals.

In this study, 24 Sprague-Dawley male rats weighing 250-300 g were used. The animals were preserved in metal cages and were fed standard food and tap water. They were kept in an environment with a controlled temperature $\left(21-22^{\circ} \mathrm{C}\right)$, humidity $(55 \%-$ $60 \%)$, and controlled photoperiod (12/12 hr light/dark) for 1 week before the start of the experiment. The body temperature of the rats was maintained using a heating lamp. The rats were randomly divided into four groups ( $n=6$ per group).

Group 1: Sham-operated rats, all the surgical steps were performed; however, T/D was not induced. The animals were kept under anesthesia for the duration of the procedure.

Group 2: The surgical procedure was performed as in the sham group; T/D was induced, but no medication was applied.

Group 3: T/D-operated rats received a single-dose injection of $10 \mathrm{mg} / \mathrm{kg}$ PM (i.p.), 60 min before detorsion. The dose of pheniramine was chosen on the basis of previous study ${ }^{4}$.

Group 4: T/D-operated rats received a single dose of $10 \mathrm{mg} / \mathrm{kg} \mathrm{NB}$ (p.o.) $60 \mathrm{~min}$ before detorsion. The dose of nebivolol was chosen on the basis of previous study ${ }^{5}$. 


\section{Experimental testicular $T / D$ procedure}

The rats were anesthetised with xylazine hydrochloride $10 \mathrm{mg} / \mathrm{kg}$ (Rompun, BayerIstanbul) and ketamine $50 \mathrm{mg} / \mathrm{kg}$ (Ketalar, Pfizer Pharma Istanbul) intramuscularly under sterile conditions. The right testis was entered through a midline incision by opening the scrotum and the lamina parietalis of the tunica vaginalis, and $T / D$ was induced by rotating the right testis $720^{\circ}$ in a clockwise direction for $2 \mathrm{hr}$. $1 \mathrm{hr}$ after torsion, group 3 and 4 rats received a single dose medication. Then, the testis was counter-rotated to the natural position and was inserted into the scrotum; the skin incision was sutured ( $6-0$ polypropylene), and animals were kept until harvesting time. We removed the right testes of six animals from each study group $4 \mathrm{hr}$ after detorsion (six hours after initiation of the experimental procedure) for the evaluation of oxidant/antioxidant balance and histopathological analysis.

\section{Statistical analysis}

All statistical examination was carried out using SPSS version15.0 (SPSS; Chicago, IL, USA). Student $t$ and Oneway ANOVA test with Bonferroni adjustment were used for comparing normally distributed data. Subsequently, the relation between these parameters was evaluated using linear regression analysis (Backward). These distinctions were accepted significant when possibility was less than 0.05 .

\section{Histopathologic evaluation}

Testis tissue samples were fixed in $10 \%$ neutral formaline for light microscopical examination. After a routine tissue preparation process, $5 \mu \mathrm{m}$ sections of the paraffin tissue blocks were stained with hematoxyleneeosin. All seminiferous tubule diameters were measured and scaled according to Johnsen's Tubular Biopsy Scores (JTBS) ${ }^{6}$ and Chart 1.
Chart 1 - Johnsen testicular biopsy score.

\begin{tabular}{|c|c|}
\hline Score & Histologic Findings \\
\hline 1 & No cells detected in the tubular section \\
\hline 2 & Only Sertoli cells are present. \\
\hline 3 & $\begin{array}{l}\text { Only spermatogonia are present as germ } \\
\text { cells. }\end{array}$ \\
\hline 4 & $\begin{array}{l}\text { There are few spermatocytes ( } 5 \text { / tubule) } \\
\text { present. }\end{array}$ \\
\hline 5 & Many spermatocytes are present. \\
\hline 6 & $\begin{array}{l}\text { There are few spermatides ( } 5 / \text { tubule) } \\
\text { present. }\end{array}$ \\
\hline 7 & $\begin{array}{l}\text { Many spermatides are present without } \\
\text { differentiation mark. }\end{array}$ \\
\hline 8 & $\begin{array}{l}\text { Young spermatides are present without } \\
\text { the presence of mature spermatocytes. }\end{array}$ \\
\hline 9 & $\begin{array}{l}\text { There are few spermatozoa ( } 5 / \text { tubule) } \\
\text { present. }\end{array}$ \\
\hline 10 & $\begin{array}{l}\text { Entire spermatogenesis with many sper- } \\
\text { matozoa is present. }\end{array}$ \\
\hline
\end{tabular}

\section{Biochemical analysis}

Total Antioxidant Status (TAS)

A TAS kit is used for the measurement of the TAS.

The TAS level was determined using the method developed by Erel. The principle of the method was based on the chemical reduction of the blue-green colored ABTS radical into the colorless ABTS form by the antioxidants. For the measurement, a spectrophotometer (Shimadzu UV 1700A) was used at $25^{\circ} \mathrm{C}$. Serum TAS levels were calculated in mmol Trolox equivalent $/ L$ with the formula $T A S=[(\triangle A b s$ standard 1)-( $\triangle$ Abs sample $)] /[(\triangle \mathrm{A}$ abs standard 1)-( $\triangle$ Abs standard 2$)]^{7}$.

\section{Total Oxidant Status (TOS)}

TOS levels were determined using a TOS kit, which operates on a novel automated and colorimetric measurement method, as previously described by Erel. The principle of the method is based on the oxidation of 
ferrous ion-chelate complex to ferric ions by the oxidants in the sample. The same spectrophotometer as described above was used, and serum TOS levels were calculated with the formula TOS $=[(\triangle \mathrm{Abs}$ serum $) /(\triangle \mathrm{Abs}$ standard)] $\times 20$ in $\mu \mathrm{mol} \mathrm{H} 2 \mathrm{O} 2$ equivalent/ $L^{8}$.

\section{Calculation of the Oxidative Stress Index (OSI)}

The TOS:TAS ratio was used as the OSI. To perform the calculation, the unit of TAS, $\mathrm{mmol}$ Trolox equivalent/ $L$, was converted to mmol Trolox equivalent/L, and the OSI was calculated as follows: OSI $=([\mathrm{TOS}, \mathrm{mmol} \mathrm{H} 2 \mathrm{O} 2$ equivalent/L]/[TAS, mmol Trolox equivalent/L] $\times 100))^{7,8}$.

\section{Paroxanase (PON)}

PON activity is measured with a commercial experimental kit (Relassay ${ }^{\circledR}$, Gaziantep, Turkey). PON measurement may be performed in the presence or absence of $\mathrm{NaCl}$, and $\mathrm{M}^{-1} \mathrm{~cm}^{-1}$ enzyme activity is calculated using the 18290 molar absorption index ${ }^{9}$.

\section{- Results}

\section{Biochemical results}

The ipsilateral evaluation of tissue TAS levels detected a statistically significant increase in Groups 3 and 4 compared to Group 1 $(p<0.001)$. There was no statistically significant difference between Group 2 and Group 3, but by comparing Group 4 with Groups 2 and 3, a statistically significant increase $(p<0.001)$ was observed (Table 2). The evaluation of tissue TOS levels indicated no significant difference by comparing Group 1 with Group 3 and Group 3 with Group 4. There was a statistically significant increase in Group 4 compared with Group 1 $(p<0.001)$. A statistically significant decrease was detected in Groups 3 and 4 compared to Group $2(p<0.001)$. When evaluating the tissue OSI levels, a statistically significant decrease was detected in Groups 3 and 4 compared to Groups 2 and $1(p<0.001)$ (Table 1$)$.

Table 1 - TAS: Total antioxidant status (TAS), TOS: Total oxidant status, OSI: Oxidative stress index, PON: Paraoxonase, T-D: Torsion-Detorsion, PM: Pheniramine Maleat, NE: Nebivolol

\begin{tabular}{|c|c|c|c|c|c|}
\hline & $\begin{array}{l}\text { Group } 1(n=6) \\
\text { (Sham) }\end{array}$ & $\begin{array}{l}\text { Group } 2(n=6) \\
\text { (T-D) }\end{array}$ & $\begin{array}{l}\text { Group } 3(n=6) \\
(T-D+F M)\end{array}$ & $\begin{array}{l}\text { Group } 4(n=6) \\
(T-D+N E)\end{array}$ & $\begin{array}{l}\text { P } \\
\text { (ANOVA) }\end{array}$ \\
\hline $\begin{array}{l}\text { TAS } \\
\text { (nmol Trolox Equiv. } \\
\text { per mg protein) }\end{array}$ & $0.45 \pm 0.08$ & $0.57 \pm 0.03$ & $0.63 \pm 0.03$ & $0.97 \pm 0.13$ & $P<0.001$ \\
\hline $\begin{array}{l}\text { TOS } \\
\text { (nmol H2O2 Equiv. } \\
\text { per mg protein) }\end{array}$ & $13.0 \pm 0.94$ & $18.10 \pm 4.03$ & $9.97 \pm 1.21$ & $7.38 \pm 1.23$ & $P<0.001$ \\
\hline $\begin{array}{l}\text { OSI } \\
\text { (arbitrary unit) }\end{array}$ & $29.53 \pm 4.30$ & $31.82 \pm 7.36$ & $15.76 \pm 2.1$ & $7.74 \pm 1.96$ & $P<0.001$ \\
\hline PON (mUl/ml) & $33.8 \pm 2.3$ & $23.2 \pm 2.7$ & $41.6 \pm 1.8$ & $52.2 \pm 1.4$ & $P<0.001$ \\
\hline
\end{tabular}

Serum PON-1 levels revealed a statistically significant increase in Groups 3 and 4 compared to Groups 1 and $2(p<0.001)$. By comparing Groups 3 and 4, a statistically significant increase was observed in favor of Group 4.
Johnsen Testicular Biopsy Score

The evaluation of the torsion groups according to the Johnsen testicular biopsy score indicated that histopathologically degeneration, desquamation, disorganisation 
of germinal cells, interstitial oedema, capillary congestion, and hemorrhage were observed as statistically significantly higher in Group 2 compared to Groups 3 and 4 (Table 2) (Figure 1).
The Johnsen testicular biopsy score is detected to have decreased in Groups 3 and 4, but the decrease was not statistically significant.

Table 2 - Distribution of histopathologic changes in the groups [slight (+), intermediate (++), strong $(+++)]$, Johnsen's Testes Biopsy Score (JTBS).

\begin{tabular}{|c|c|c|c|c|c|}
\hline Parameters & $\begin{array}{l}\text { Group } 1 \\
(n=6) \\
\text { (Sham) }\end{array}$ & $\begin{array}{l}\text { Group } 2 \\
(n=6) \\
(I / R)\end{array}$ & $\begin{array}{l}\text { Group } 3 \\
(\mathrm{n}=6) \\
(\mathrm{I} / \mathrm{R}+\text { Pheniramine } \\
\text { Maleate } \mathrm{mg} / \mathrm{kg})\end{array}$ & $\begin{array}{l}\text { Group } 4 \\
(n=6) \\
(1 / R+\text { Nebivolol } \\
\mathrm{mg} / \mathrm{kg})\end{array}$ & $\begin{array}{l}\text { P } \\
\text { (ANOVA) }\end{array}$ \\
\hline Desquamation in germinal cells & ND & +++ & ++ & + & $<0.05$ \\
\hline $\begin{array}{l}\text { Disorganisation in germinal } \\
\text { cells }\end{array}$ & ND & +++ & ++ & + & $<0.05$ \\
\hline Degeneration in germinal cells & ND & +++ & ++ & + & $<0.05$ \\
\hline Haemorrhage & ND & +++ & ++ & + & $<0.05$ \\
\hline $\begin{array}{l}\text { Interstitial oedema and } \\
\text { capillary congestion }\end{array}$ & ND & +++ & ++ & + & $<0.05$ \\
\hline $\begin{array}{l}\text { Reduction in germinal cell } \\
\text { counts }\end{array}$ & ND & +++ & ++ & + & $<0.05$ \\
\hline $\begin{array}{l}\text { Testes histology score count } \\
\text { (JTBS) }\end{array}$ & $9.5 \pm 0.4$ & $9.0 \pm 0.4$ & $9.2 \pm 0.4$ & $9.3 \pm 0.4$ & $>0.05$ \\
\hline
\end{tabular}

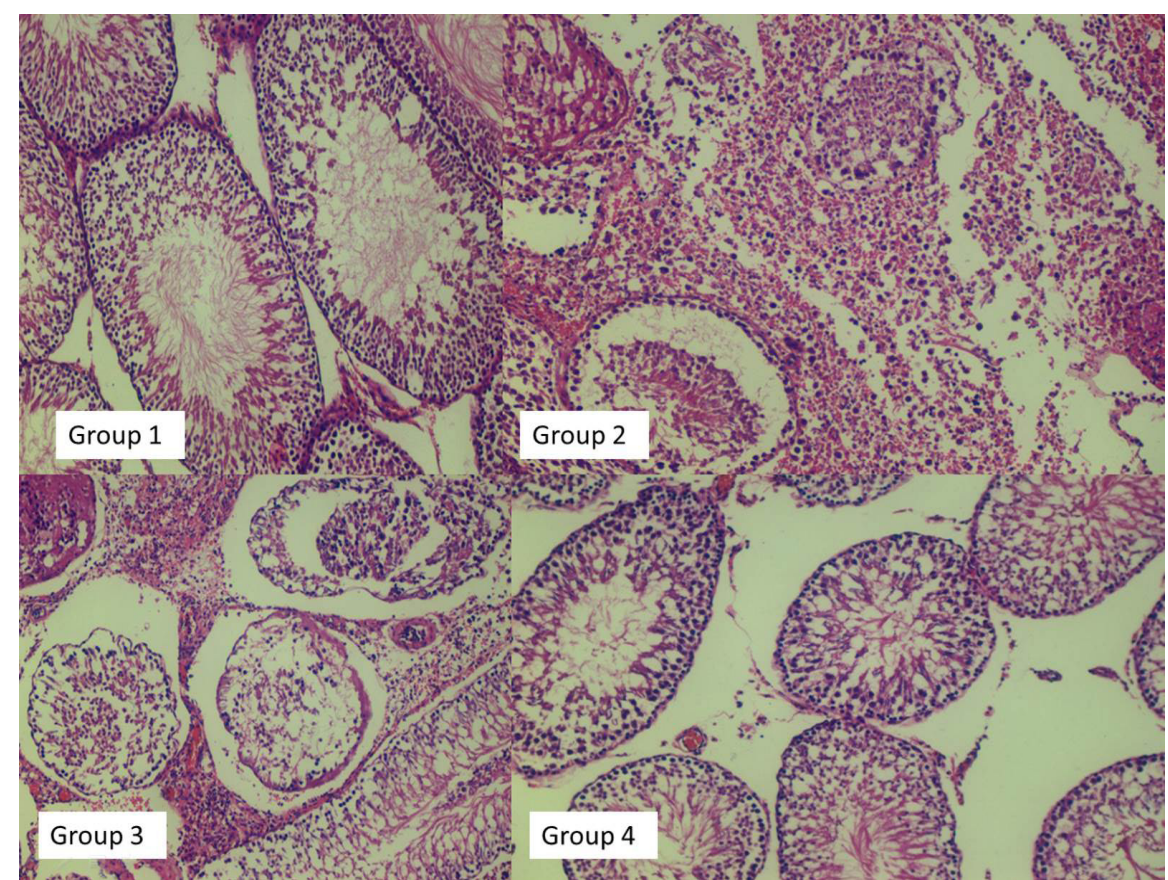

Figure 1 - Group 1: Sham (n=6), Group 2: I/R (n=6), Group 3: I/R + Pheniramine maleate (n=6), Group 4: I/R + Nebivolol ( $n=6)$ (x100, Hemotoxylen-Eosin). 


\section{- Discussion}

Testis torsion is an emergency requiring prompt diagnosis and necessary surgical intervention to prevent testicular necrosis or dysfunction, which may result in future infertility and therefore is a major fear of the families of the boys affected. Testicular torsion is primarily observed in boys in the neonatal or puberty period. The yearly incidence among boys younger than 18 years is $3.8 / 100000$, and surgical intervention is required in $41.9 \%$ of cases $^{10}$.

Two determinant factors of testicular atrophy are the time period between the beginning of the symptoms and the detorsion and the rotation degree of the spermatic cord. The occurance of severe testicular atrophy is variable; it may occur in a short time, e.g., 4 hours if the spermatic cord is twisted 360 degrees, or no atrophy can be detected in cases with incomplete torsion (180-360 $)$ even after 12 hours $^{11}$.

In another study, the complete deterioration in spermatogenesis after unilateral testis torsion was found to occur in $50 \%$ of the cases where a borderline deterioration is observed in $20 \%$ of the other $50 \%{ }^{12}$. Another study revealed subfertility in $36-39 \%$ of patients after unilateral testis torsion/detorsion. In the long-term followup of these, normal semen parameters were found in $5-50 \%{ }^{13}$.

Subfertility and infertility are primarily associated with the blockage of the testicular blood flow, but free radicals developing after reperfusion also play an important role. Testis torsion causes ischemic damage where detorsion is responsible for the development of biochemical and structural changes in the tissue. Studies have shown that ischemia reperfusion tissue damage occurs due to free oxygen radicals (FORs). FORs disrupt the structural elements of the tissue and cause damage. Many studies have reported on I/R damage and the effects of antioxidant therapy in reducing this damage. There are several antioxidant defense mechanisms to remove FORs in the cells. Reperfusion damage is found to be closely associated with neutrophil infiltration and the increase in FORs. These FORs increase the membrane's permeability because of the peroxidation of its lipid elements, protein denaturation, and cell damage. They also enhance the germ cell damage due to ischemia ${ }^{14-16}$. The search for antioxidant agents that can prevent I/R damage and preserve detorsionated and contralateral testis function continues. New treatment strategies like natural products, vitamines, selenium, hormones, hormone receptors, vascular agents, phosphodiesterase inhibitors, anestetic and nonsteroid antiinflammatory drugs, mucolytic agents, and hyperbaric oxygen therapy are introduced to prevent I/R damage, but no consensus could be reached on the clinical use. The protective effect of antihistaminics against the harmful effects of free radicals has attracted attention in recent years. PM is an alcali-erived antihistaminic, which is believed to adhese to cell membranes because of its lipophilic feature and inhibit the formation and/or secretion of free radicals.

In vitro studies have shown that the formation of free radicals occurs through activated neutrophils. It is believed that the antioxidant effect of $\mathrm{H} 1$ antihistaminics helps to decrease tissue damage. Nosalova and Bayrak have shown the I/R damage-prevention effect on gastrointestinal and renal systems, respectively ${ }^{4,17}$. PM is widely used for the treatment of allergy and cold symptoms and has an anti-inflammatory effect, which functions through the transcription factor NF-kB. It affects I/R damage by inhibiting the secretion of some mediators in the inflammatory process ${ }^{1}$.

Yürekli et al. ${ }^{18}$ illustrated the protective effect of PM by I/R damage in the brain tissue, while Nosalova et al. ${ }^{4}$ obtained similar results by mesenteric I/R damage. Gökalp et al. ${ }^{1}$ have 
detected that PM has a protective effect on the I/R damage of lung tissue through the inhibition of the inflammatory mediators.

NB is a third-generation highly selective beta-1 receptor antagonist and is widely used orally to treat arterial hypertension. It has endothelium-dependent vasodilatation features due to the secretion of endotheliumderived relaxing factor and NO. NB is a negative inotrop and beta 3 receptor agonist agent, and the NO synthesis takes place by inducing the beta 3 receptors. It is shown that long-term use of NB develops the endothel function, prevents vascular superoxide production by producing NADPH oxidase, and supresses vascular oxidative stress in antihypertensive doses ${ }^{2,3,19,20}$. In an endothel function study, it was detected that NB decreased the oxidative stress agent endothelin-1 production and secretion in smooth muscle cells ${ }^{21}$.

Gandhi et $a .^{22}$ reported that NB has a protective effect against renal $I / R$ damage because of its beta 1 adrenoreceptor blocker activity and apoptotic and anti-inflammatory features. Soydan et al. ${ }^{19}$ demonstrated that L-NB has a supportive effect on endothelial and ileal dysfunction after superior mesenteric artery I/R damage. de Groot et al. ${ }^{5}$ reported on the antioxidant activity in their aorta study, while Illhan et $a .^{23}$ illustrated its protective effect on I/R damage of the spinal cord. Heeba et $a .^{24}$ detected the oxidative stress-reducing effect and Uzar et al. ${ }^{20}$ antioxidant and antiapoptotic effects of NB by cerebral I/R damage.

TAS measurement gives more information than the measurement of the antioxidants individually. For this reason, TAS measurement is widely used to determine the total antioxidant capacity. Studies have shown that PON may be an indicator of the antioxidant system of the body and therefore can be used as a biomarker ${ }^{25-27}$. The OSI is a parameter showing the tendence of oxidants and antioxidants in the oxidant/antioxidant balance and can be calculated by the division of the total oxidants by the total antioxidants. The OSI is a marker that can indicate lipid peroxidation, protein oxidation, and DNA damage caused by the uncompensated free radicals formed due to the increase of the oxidants or decrease of the antioxidants. In addition, several methods are used to evaluate the oxidative stress and the antioxidant status, but higher costs and time investment are needed to determine and measure them individually. Therefore, TOS, TAS, and PON are measured and the OSI has been calculated in recent years ${ }^{28}$.

In our study, we detected that the application of PM and NB has increased TAS and decreased TOS and the OSI, indicating the antioxidant feature of PM and NB. Histopathologically, it was detected that in the study groups with PM and NB application, the I/R damage tended to recover, which was observed more potently in the NB group. According to these results, we can see that NB has an antioxidant effect, protects the testis tissue, and supports recovery histopathologically by testis torsion. We observed similar effects with PM as well, but not as potent as NB.

In this study, it was shown that $I / R$ damage occurs after testis torsion histologically and biochemically, which caused impaired spermatogenesis and may eventually lead to subfertility and infertility. PM and NB have reversed this negative effect after a single administration. These results are promising for the use of these agents as future drugs to recover testis damage. PM and NB treatments also decreased the OSI and TOS levels significantly and increased the PON and TAS levels, which indicate the antioxidant capacity in the testis tissue (Table 1). Oxidative stress activates pathways for the synthesis of proinflammatory cytokines and cell adhesion molecules. For this reason, oxidative stress may have a positive effect on the inflammatory response after testis I/R induced by endotoxemia. Our data revealed that spermatogenetic dysfunction due to oxidative stress developed after testis I/R and 
that PM, and more significantly, NB application provides histopathological enhancement (Figure 1). The findings of this study support the consideration that PM and NB protect testicular function after $\mathrm{I} / \mathrm{R}$ by reducing the oxidative stress.

\section{Conclusions}

Pheniramine maleate and nebivolol have antioxidant effects against ischemiareperfusion damage. They also support tissue recovery, which is more significantly observed by nebivolol.

\section{References}

1. Gokalp O, Yurekli I, Kiray M, Bagriyanik A, Yetkin U, Yurekli BS, Gür S, Aksun M, Satoglu IS, Gokalp G, and Gürbüz A. Assessment of protective effects of pheniramine maleate on reperfusion injury in lung after distant organ ischemia: a rat model. Vasc Endovasc Surg. 2013;47(3):219-24. PMID: 23377174.

2. Ulger BV, Kapan M, Uslukaya O, Bozdag Z, Turkoglu A, Alabalık U, Onder A. Comparing the effects of nebivolol and dexpanthenol on wound healing: an experimental study. Int Wound J. 2016 Jun;13(3):367-71. doi: 10.1111/iwj.12314.

3. Toblli JE, DiGennaro F, Giani JF, Dominici FP. Nebivolol: impact on cardiac and endothelial function and clinical utility. Vasc Health Risk Manag. 2012;8:151-60. PMID: 22454559.

4. Nosalova V, Drabikova K, Jancinova V, Nosal R, Macickova T, Pecivova J, Nedelcevova J, Sotnakova R. Protective effect of pheniramines against mesenteric ischaemia/ reperfusion-induced injury. Inflamm Res. 2009;58(1):68-9. doi: 10.1007/s00011-0092011-5.

5. de Groot AA, Mathy MJ, van Zwieten PA, Peters SL. Antioxidant activity of nebivolol in the rat aorta. J Cardiovasc Pharmacol. 2004;43:148-53. PMID: 14668581.

6 . Johnsen SG. Testicular biopsy score count-a method for registration of spermatogenesis in human testes: normal values and results of 335 hypogonadal males. Hormones. 1970;1:2-25. PMID: 5527187.
7. Erel O. A novel automated direct measurement method for total antioxidant capacity using a new generation, more stable ABTS radical cation. Clin Biochem. 2004;37:277-85. PMID: 15003729.

8. Erel O. A new automated colorimetric method for measuring total oxidant status. Clin Biochem. 2005;38:1103-11. PMID: 16214125.

9. Toy H, Camuzcuoglu H, Celik H, Erel O, Aksoy $\mathrm{N}$. Assessment of serum paraoxonase and arylesterase activities in early pregnancy failure. Swiss Med Wkly. 2009;139:76-81. PMID: 19204840.

10.Zhao LC, Lautz TB, Meeks JJ, Maizels M. Pediatric testicular torsion epidemiology using a national database: incidence, risk of orchiectomy and possible measures toward improving the quality of care. J Urol. 2011;186(5):2009-13. PMID: 21944120.

11.Sessions $A E$, Rabinowitz $R$, Hulbert WC, Goldstein MM, Mevorach RA. Testicular torsion: direction, degree, duration and disinformation. J Urol. 2003;169:663-5. PMID: 12544339.

12.Visser AJ, Heyns CF. Testicular function after torsion of the spermatic cord. BJU Int. 2003;92:200-3. PMID: 12887467.

13.Anderson MJ, Dunn JK, Lipshultz LI, Coburn M. Semen quality and endocrine parameters after acute testicular torsion. J Urol. 1992;147:1545-50. PMID: 1593686.

14.Cuzzocra S, Riley DP, Caputi AP, Salvemini D. Antioxidant therapy: a new pharmacological approach in shock, inflammation, and ischemia/reperfusion injury. Pharmacol Rev. 2001;53(1):135-59. PMID: 11171943.

15.Lysiak JJ, Nguyen QA, Turner TT. Peptide and non peptide reactive oxygensca ven gerspro vi de partial rescue of the testis after torsion. J Androl. 2002;23(3):400-9. PMID: 12002442.

16. Filho DW, Torres MA, Bordin AL, CrezcynskiPasa TB, Boveris A. Spermatic cord torsion, reactive oxygen and nitrogen species and ischemia-reperfusion injury. Mol Aspects Med. 2004;25:199-210. PMID: 15051328.

17.Bayrak S, Yurekli I, Gokalp O, Kiray M, Bademci MS, Ozcem B, Besir Y, Yilik L, Kestelli M, Gurbuz A. Assessment of protective effects of methylprednisolone and pheniramine maleate on reperfusion injury in kidney after distant organ ischemia: 
a rat model. Ann Vasc Surg. 2012;26(4):55965. PMID: 22445244.

18.Yürekli I, Gökalp O, Kiray M, Gökalp G, Ergüneş K, Salman E, Yürekli BS, Satoğlu IS, Beşir Y, Cakır H, Gürbüz A. Effect of pheniramine maleate on reperfusion injury in brain tissue. Med Sci Monit Basic Res. 2013;19:285-90. PMID: 24309384.

19.Soydan G, Cekic EG, Tuncer M. Nebivolol has protective effect against endothelial and ileal dysfunction due to I/R. J Surg Res. 2011;166:156-61. doi: 10.1016/j. jss.2009.06.022.

20.Uzar E, Acar A, Evliyaoglu O, Fırat U, Kamasak K, Göcmez C, Alp H, Tüfek A, Tasdemir N, Ilhan A. The anti-oxidant and anti-apoptotic effects of nebivolol and zofenopril in a model of cerebral ischemia/reperfusion in rats. Prog Neuropsychopharmacol Biol Psych. 2012;36:22-8. PMID: 21888941.

21.Ganz P, Vita JA. Testingendothelial vasomotor function: nitric oxide, a multipotent molecule. Circulation. 2003;108:2049-53. PMID: 14581383.

22.Gandhi C, Zalawadia R, Balaraman R. Nebivolol reduces experimentally induced warm renal ischemia reperfusion injury in rats. Ren Fail. 2008;30:921-30. PMID: 18925533.

23.Ilhan A, Yilmaz HR, Armutcu F, Gurel A, Akyol $O$. The protective effect of nebivolol on ischemia/reperfusion injury in rabbit spinal cord. Prog Neuropsychopharmacol Biol Psychiatry. 2004 Nov;28(7):1153-60. PMID: 15610928.

24. Heeba GH, El-Hanafy AA. Nebivolol regulates eNOS and iNOS expressions and alleviates oxidative stress in cerebral ischemia/reperfusion injury in rats. Life Sci. 2012;90:388-95. PMID: 22226906.

25.Topsakal C, Kilic N, Ozveren F, Akdemir I, Kaplan M, Tiftikci M, Gursu F. Effects of prostaglandin E1, melatonin, and oxytetracycline on lipid peroxidation, antioxidant defense system, paraoxonase (PON1) activities, and homocysteine levels in an animal model of spinal cord injury. Spine. 2003;28:1643-52. PMID: 12897486.

26. Costa LG, Giordano G, Furlong CE. Pharmacological and dietary modulators of paraoxonase 1 (PON1) activity and expression: the hunt goes on. Biochem Pharmacol. 2011;81:337-44. PMID: 21093416.

27.Vasdev S, Gill V, Singal PK. Benecial efect of low ethanol intake on the cardiovascular system: possible biochemical mechanisms. Vasc Health Risk Manag. 2006;2:263-76. PMID: 17326332.

28. Kohen R, Nyska A. Oxidation of biological systems: oxidative stress phenomena, antioxidants, redox reactions, and methods for their quantification. Toxicol Pathol. 2002;30:620-50. PMID: 12512863.

\section{Correspondence:}

Devrim Tuglu

Kirikkale University, School of Medicine, Department of Urology

71100 Kirikkale Turkey

Phone: (0318)3335000-5439

Fax: (0318)2252819

devrimtuglu@gmail.com

Received: Oct 10, 2017

Review: Dec 12, 2017

Accepted: Jan 11, 2018
Conflict of interest: none

Financial source: none 